DOI: $10.21802 / \operatorname{artm} .2019 .4 .12 .73$.

УДК $311.21+314.118$

\title{
ВИЯВЛЕННЯ МАТЕМАТИЧНОЇ ЗАЛЕЖНОСТІ МІЖ ЯКІСНИМИ ТА КІЛЬКІСНИМИ ПОКАЗНИКАМИ ПРОВЕДЕНОГО ДОСЛІДЖЕННЯ ДОВГОЖИТЕЛІВ
}

\section{Р.В. Козовий}

\author{
Івано-Франківський національний медичний університет, кафедра медичної біології та медичної \\ генетики, Івано-Франківськ, Україна, \\ ORCID ID: 0000-0002-1806-9773, \\ e-mail:ruslan_kozoviy@ukr.net
}

Резюме. Збільшення тривалості життя населення планети закономірно викликає зростання вік-залежної патології. Вивчення первинних механізмів старіння організму й популяції дасть змогу розширити об'єм предиктивних заходів, спрямованих на збереження здоров'я. 3 метою дослідження взаємозв'язків екзогенних та ендогенних чинників, їх впливу на формування тривалості життя проведено комплексне дослідження 486 довгожителів і 297 осіб групи порівняння, які тривалий час проживали на території Івано-Франківської області. Після попереднього комплексного дослідження (епідеміологічним, загальноклінічнми, клініко-генеалогічним, цитогенетичним, морфоденситометричним, електронномікроскопічним, молекулярно-генетичним, біохімічним методами) отримані результати порівняли в двох досліджуваних групах. Нами використано математичний метод співвідношення шансів (Odds Ratio (OR)) та метод парної кореляції Пірсона з допомогою прикладної програми Statistica. За результатами порівняльного аналізу достовірності різниці даних у групах порівняння відібрані ті, які суттєво відрізняються, для подальшого кореляційно-регресійного факторного аналізу. Шляхом поступового вилучення несуттєвих взаємозв'язків отримали дві математичні моделі. Таким чином встановлені взаємозв'язки між деякими цитогенетичними показниками довгожителів Прикарпаття, які дали змогу сформувати дві математичні моделі рівнянь множинної регресії (за діапазоном мінливості ядер слизової оболонки ротової порожнини, мінімальною оптичною щільністю, мікроядрами епітеліоцитів слизової оболонки ротової порожнини, морфологічно зміненими ядрами нейтрофілів та окисними модифікаціями білків).

Ключові слова: довголіття, екзогенні чинники, стан здоров'я, тривалість життя.

Вступ. Оскільки очікувана при народженні тривалість життя в усьому світі збільшується, важливим завданням геронтології є забезпечення доброго здоров'я, активної діяльності людей похилого віку. Вирішити цю проблему можна шляхом досліджень фундаментальних механізмів старіння i факторів довголіття [1]. Останніми роками значна кількість наукових робіт зосереджена на встановленні ролі спадковості, зокрема функції окремих генів, їх поліморфізмів, що сприяють активному довголіттю [2]. Наші попередні дослідження були присвячені також визначенню внеску генетичних чинників та факторів довкілля у формування тривалості життя [3]. Відомо, що довголіття, як мультифакторна ознака, реалізується за участі і спадкових, і екзогенних факторів довкілля, включно із стохастичними [4]. Тому важливо не лише ідентифікувати гени, які впливають на тривалість життя і розвиток асоційованих $з$ віком захворювань, але й виявляти значущість для реалізації потенціалу здорового старіння екологічних умов проживання, соціальнопсихологічних чинників, способу життя, харчування тощо [5]. Вищеописане підтверджують дані BOO3 про вагомий внесок у формування здоров'я сучасної людини умов і способу життя (50 \%) та стану довкілля (20-22 \%), 20 \% - генетичні фактори, 8-10 $\%$ - рівень розвитку охорони здоров'я.
Мета дослідження: встановити взаємозв'язки між екзо- та ендогенними чинниками у довгожителів Прикарпаття.

Матеріали і методи. Обстежено 486 довгожителів, які тривалий час проживали на території Івано-Франківської області, та 297 осіб віком від 36 до 60 років, у родоводах яких не було довгожителів.

Після попередньо проведеного комплексного дослідження (епідеміологічним, загальноклінічнми, клініко-генеалогічним, цитогенетичним, морфоденситометричним, електронномікроскопічним, молекулярно-генетичним, біохімічним методами) отримані результати порівняли в двох досліджуваних групах. При проведенні аналізу отриманих результатів виникла потреба у порівнянні впливу різних чинників на досліджувану ознаку. Оскільки наявність або відсутність значущості такої ознаки є якісним показником, нами використано математичний метод співвідношення шансів (Odds Ratio (OR)) [6]. Він дозволяє визначити ймовірність впливу кожного із 49 факторів на формування довголіття шляхом кореляційного та багатофакторного аналізу, який здійснювався 3 використанням можливостей програми статистичного аналізу Statistica (v.10). Для кореляційного аналізу 29 кількісних морфологічних, генетичних, біохімічних показників використано метод парної кореляції Пірсона 3 допомогою прикладної програми Statistica. 
3 метою вибору адекватних методів описання центральної тенденції досліджуваних ознак та порівняльного аналізу достовірності їх різниці у двох групах (довгожителів і контрольній) всі варіаційні ряди оцінили на тип розподілу даних за методом Колмогорова-Смірнова [7].

Результати дослідження та їх обговорення. Останніми роками все більша увага приділяється клітинним, цитогенетичним і біохімічним факторам старіння [8]. Це зумовлено тим, що з віком знижується стійкість організму до гіпоксії i, як наслідок, розвивається гіпоксичне порушення гомеостазу. Першочергово зміни про- і антиоксидантної систем проявляються на клітинному рівні. При старінні відбувається порушення балансу між інтенсивністю утворення вільних радикалів і активністю антиоксидантної системи [9]. Оксидантний стрес веде до збільшення продукції в тканинах активних форм кисню (АФК), що зумовлює зниження адаптивних можливостей у літніх людей. Посилення перекисного окиснення ліпідів і білків призводить до порушення функції клітинних мембран, утворення та відновлення органел, нуклеосомної природи хромосомного апарату. Отже, вищеописані процеси пов'язані зі змінами структури клітин, іï морфометричних характеристик, а особливо перебудови хроматину, експресії та функції генів. Останнє детермінує формування фенотипових ознак, зокрема синтезу поліпептидів, ферментів.

Тому оцінка цитогенетичного статусу організму є невідкладною складовою у створенні цілісної картини клітинних аспектів старіння. На першому етапі нами був здійснений пошук взаємозв'язків між клітинними, цитогенетичними і біохімічними факторами старіння.

Стан глутатіонової системи, як компоненту ендогенної антиоксидантної системи, оцінювали за активністю ферментів глутатіон-S-трасферази (GST), глутатіонпероксидази (GPO), глутатіонредуктази (GRO). Продукти окисної модифікації білків (ОМБ) у сироватці крові досліджували відповідним методом О.Ю. Дубініної. Функціональний стан геному епітеліоцитів слизової оболонки ротової порожнини (СОРП), лімфоцитів периферійної крові (ЛПК) та нейтрофільних гранулоцитів периферійної крові (НГПК) встановлювали за індексами хроматизації (IX), ядерцевим (ЯI), морфологічно змінених ядер (МЗЯ), гетеропікнотичної X-хромосоми (CX). Структурні зміни хромосомного апарату визначали за частотою мікроядер (МЯ) в СОРП, хромосомними абераціями (ХА), асоціаціями акроцентричних хромосом (AАХ) у метафазних пластинках ЛПК. 3 морфометричних параметрів соматичних клітин вибрано площу та периметр ядер, із спектрометричних - оптичну та інтегральну щільність ядер епітеліоцитів СОРП, ЛПК.

Кореляційним аналізом встановлено наявність чотирьох дуже сильних позитивних зв'язків у довгожителів $(\mathrm{r}=0,90)$. Перший 3 них - між ступенем компактизації хроматину в ядрах епітеліоцитів СОРП і ЛПК, довів узгодженість процесів експресії генів у різних клітинах і достатній рівень регуляції біосинтезу поліпептидів. Закономірними виявилися кореляції між різними фракціями ОМБ: ОМБ 356 і ОМБ 370 , ОМБ $356{\text { i } \mathrm{OMБ}_{430}, \mathrm{OMБ}_{370} \text { і ОМБ}}_{430}$. Наявність лише одної дуже сильної кореляції $(\mathrm{r}=0,90-0,99)$ у представників контрольної групи (між ОМБ 370 і ОМБ 430 ) може свідчити про виснаження резервно-адаптаційних можливостей організму. Натомість у довгожителів ступінь окиснювальної деструкції білкової молекули порівняно менший.

Важливу роль у продовженні тривалості життя відіграють, за даними кореляційного аналізу, оптимальні зв'язки між ферментами глутатіонової системи і показниками окиснення білків [10]. У довгожителів виявлено п'ять значних кореляцій $(\mathrm{r}=0,5-$ $0,69)$, дві з яких обернені. Закономірним був обернений взаємозв'язок між активністю GST і GPO. Відомо, що GST бере участь у першому етапі детоксикації, каталізує взаємодію ксенобіотиків з глутатіаном. Таким чином GST запобігає пошкодженню ДНК, мітохондрій, інших життєво важливих органел від дії шкідливих речовин. Подібну функцію виконує і GPO, який не лише попереджає накопичення гідроперекисів, а й активно їх відновлює. Сумісно ці два ферменти гальмують подальше прогресування пероксидації, поширення неферментних реакцій накопичення вторинних метаболітів. Ймовірно, однонаправленість діï GPO i GST зумовлює обернений зв'язок між їх активністю.

Важливим доказом високого рівня активності детоксикації ксенобіотиків у довгожителів $є$ наявність двох значних позитивних кореляцій між GPO та ступенем конденсації хроматину в епітеліоцитах СОРП і ЛПК. Збільшення в ядрах цих клітин евхроматинових фракцій може зумовлювати активацію транскрипції та, відповідно, наступних етапів реалізації спадкової інформації, зокрема, синтезу поліпептиду ферменту GPO.

Відомо, що окиснювальна деструкція білків одна з важливих причин інактивації ферментів, зміни структурної організації білків при стані окиснювального стресу. Тому відсутність значних кореляцій між ОМБ, ферментами глутатіонової системи та цитоморфометричними і денситометричними показниками, на противагу до таких у контрольній групі (11 кореляцій), опосередковано вказує на високий рівень ендогенних антиоксидантів у довгожителів. Заслуговує на увагу обернений взаємозв'язок між ОМБ $530 \mathrm{i}$ максимальною оптичною щільністю ядер СОРП довгожителів. Переважання нейтральних фракцій ОМБ може спостерігатися в білках цитоплазми і клітинної мембрани. Змінені інтегральні або периферійні білки, які формують структуру останньої, не дають змоги фракціям конденсованого хроматину з'єднуватися 3 цитолемою. Тому гетерохроматин локалізується окремими грудками в каріоплазмі, що збільшує показник максимальної оптичної щільності ядра.

Порівняльний аналіз взаємозв'язків між 29 показниками осіб двох досліджуваних груп показав, що у довгожителів кількість кореляцій помірної сили $(\mathrm{r}=0,30-0,49)$ була меншою (34), ніж у людей контрольної групи (51). Визначальною особливістю якості зв'язків у довгожителів була участь ферментів глутатіонової системи у 44,12 \% різних кореляцій. Натомість у людей групи порівняння виявлена тільки 
одна кореляція серед усіх (1,96 \%), що мала відношення до GRO - між активністю GRO та ОМБ 356 .

Потребують детального пояснення типи взаємозв'язків між ферментами глутатіонової системи та цитоморфометричними i цитогенетичними показниками. Збільшення периметру ядер за рахунок інвагінацій каріолеми, посилення оптичної щільної ядер може бути відображенням гетерохроматизації. Це не сприяє синтезу поліпептидів i, відповідно, ферментів GPO і GST, на що вказують від'ємні кореляції між зазначеними показниками. Однак, регуляція експресії генів GPO може бути забезпечена за рахунок оптимального контролю сайтів X-хромосоми, що засвідчено позитивним взаємозв'язком (r=0,30-0,49). Встановлено також позитивний взаємозв'язок між активністю GPO та здатністю акроцентричних хромосом утворювати асоціації. Відомо, що найбільш інформативним цитогенетичним показником імунореактивності лімфоцитів у різних фазах всіх видів імунної відповіді в організмі людини на момент дослідження є частота ААХ. Це зумовлено тим, що важлива функція акроцентричних хромосом полягає в утворенні ядерця. В останньому відбувається синтез рРНК, з якої в цитоплазмі формуються рибосоми. Окрім того, з активністю ядерця пов'язані транспорт різних видів РНК з ядра в цитоплазму. Тобто, активність біосинтетичних процесів у клітині безпосередньо залежить від функції ядерцевих організаторів. Можна припустити, що частота AAX у лімфоцитах відображає функціональний стан клітини в передуючій інтерфазі. При цьому, за нашими даними, цей показник досягав максимуму у людей зрілого віку i знижувався в похилому віці. Оскільки в довгожителів імовірність утворення ААХ більша, ніж у людей групи порівняння, активність біосинтетичних процесів ферменту ГП також вища. Цей факт може бути ще одним доказом функціональної активності ферментів глутатіонової системи як складової ендогенного антиоксидантного захисту в довгожителів.

Цитогенетичними маркерами достатньої продукції GRD і GST є встановлені позитивна кореляція між активністю GRD та IX i, відповідно, від'ємна кореляція між GST і максимальною оптичною щільністю ядра. Гетерохроматизація асоціюється зі зниженням здатності деспіралізації ДНК та першого етапу експресії генів. Саме $з$ таких позицій можна розглядати обернені взаємозв'язки між максимальною оптичною щільністю та IX, позитивні - між діапазоном оптичної щільності та IX різних соматичних клітин. Варто зазначити про узгодженість деконденсації хроматину з показником СX у лімфоцитах, нейтрофілах і епітеліоцитах СОРП, що засвідчили чотири позитивні кореляції. Такої універсальної оптимально-адекватної взаємодії між активністю евхроматину та регулярною функцією Х-хромосоми не виявлено в осіб контрольної групи. У людей, в родоводах яких не було довгожителів, між вищезазначеними показниками спостерігалися від'ємні кореляції. Водночас 17 взаємозв'язків зареєстровано між ОМБ і денситометричними, цитогенетичними індексами.
Чим більше з'являлося ОМБ, тим більш вираженими були зміни структури хроматину, ядер. Поява МЯ в лімфоцитах, епітеліоцитах СОРП також залежала від активності ОМБ 370 та ОМБ 430 відповідно. При цьому достатньої кількості GRD і GPO, які попереджають накопичення гідроперекисів (а GST ще й відновлює останні), у людей контрольної групи не встановлено.

Отже, окиснювальна деструкція білків - одна 3 можливих причин інкактивації ферментів глутатіонової системи, яка належать до ендогенних чинників антиоксидантних систем. Окисні модифікації білків зумовлюють зміни структури та функції клітинних компонентів, що демонструють зростання частоти МЯ, патологічних ядер, максимальної оптичної щільності ядер, гетерохроматизації. Такі процеси супроводжуються дисрегуляторним впливом гетеропікнотичної Х-хромосоми у людей похилого віку.

У довгожителів достовірно переважала активність ферментів глутатіонової системи. Глутатіон трансфераза знешкоджує сполуки майже всіх класів: різні токсичні речовини, канцерогени, мутагени, цитостатики, пестициди, фарби, ліки тощо. Речовини, з'єднані з GST, поступово інактивуються і виводяться, не пошкоджуючи клітину. Глутатіон редуктаза необхідна для відновлення окиснювального глутатіону, а разом із GPO підтримує певний рівень відновленого глутатіону.

На відміну від людей похилого віку, у довгожителів активність GST не знижена. Можна припустити, що саме тому в соматичних клітинах довгожителів спостерігалася невелика кількість змінених мітохондрій, елементів комплексу Гольджі та ендоплазматичної сітки. Пошкодженню цих органел запобігала GST, що значно збільшувало стійкість клітин і цілого організму. Сумісно ферменти глутатіонової системи попереджають подальше прогресування пероксидації, накопичення вторинних метаболітів.

Оскільки абсолютна більшість досліджуваних параметрів не відповідала нормальному типу розподілу даних, то для їх обробки та подальшого аналізу використовували методи не параметричної статистики. Результати порівняльного аналізу досліджуваних кількісних факторів у групі довгожителів та контрольній представлені у таблиці 1 .

За результатами порівняльного аналізу достовірності різниці даних у групах порівняння відібрані ті, які суттєво відрізняються, для подальшого кореляційно-регресійного факторного аналізу.

Враховуючи, що у дослідженні аналізувалось значна кількість показників, для вибору найвагоміших чинників довголіття застосували методику множинного факторного аналізу. За його результатами (табл. 2), виділено два основних результуючих фактори - 356 і мінімальна оптична щільність ядер. Навколо встановлених результуючих факторів сформовані два кластери факторіальних показників, підтверджені евклідовими відстанями (рис.1). 
Таблиця 1

Порівняльний аналіз кількісних факторів у досліджуваній та порівняльній групах

\begin{tabular}{|c|c|c|c|c|c|}
\hline $\begin{array}{c}\text { Показники досліджуваної } \\
\text { групи }\end{array}$ & $\begin{array}{c}\text { Lower } \\
\text { (нижня межа) }\end{array}$ & $\begin{array}{c}\text { Upper } \\
\text { (верхня межа) }\end{array}$ & $\begin{array}{c}\text { Std.Dev. } \\
\text { (стандартне квадра- } \\
\text { тичне відхилення) }\end{array}$ & $\begin{array}{l}\text { Standard } \\
\text { (норма) }\end{array}$ & $\mathbf{P}$ \\
\hline GPO & 0,1800 & 0,4500 & 0,17514 & 0,022610 & 0,297726 \\
\hline GRD & 0,1400 & 0,2550 & 0,11467 & 0,014804 & 0,000000 \\
\hline GST & 0,1250 & 0,3350 & 0,28549 & 0,036857 & 0,005690 \\
\hline ОМБ 356 & 0,8753 & 1,3240 & 0,35711 & 0,046103 & 0,000001 \\
\hline ОМБ 370 & 0,8319 & 1,2240 & 0,29982 & 0,038706 & 0,000004 \\
\hline ОМБ 430 & 0,4153 & 0,5636 & 0,11600 & 0,014975 & 0,556227 \\
\hline ОМБ 530 & 0,1472 & 0,1961 & 0,04631 & 0,005979 & 0,356559 \\
\hline периметр ядра & 54,9950 & 66,0100 & 9,18649 & 1,185970 & 0,002454 \\
\hline площа ядра & 233,7800 & 260,8450 & 19,08202 & 2,463478 & 0,000000 \\
\hline міn оптична щільність & 52,0000 & 58,6000 & 4,13136 & 0,533356 & 0,000000 \\
\hline мах оптична щільність & 106,7500 & 125,9000 & 25,53359 & 3,296372 & 0,000000 \\
\hline діапазон мінливості & 54,5500 & 61,9500 & 6,16986 & 0,796525 & 0,000000 \\
\hline відношення ядер & 0,5800 & 0,9200 & 0,25061 & 0,032353 & 0,585556 \\
\hline відсоток ААХ & 79,4500 & 102,5000 & 14,34641 & 1,852114 & 0,331567 \\
\hline середнє значення АAX & 1,1850 & 1,8115 & 0,54548 & 0,070422 & 0,012131 \\
\hline середня кількість АХ & 2,6600 & 3,1800 & 0,34176 & 0,044120 & 0,000033 \\
\hline IX епітеліоцити & 0,6050 & 0,8550 & 0,18501 & 0,023885 & 0,122493 \\
\hline ЯІ епітеліоцити & 3,3950 & 3,8450 & 0,33924 & 0,043796 & 0,000000 \\
\hline СХ епітеліоцити & 12,5500 & 14,5000 & 1,38153 & 0,178354 & 0,000037 \\
\hline МЗЯ епітеліоцити & 4,7850 & 5,6550 & 0,62337 & 0,080476 & 0,000000 \\
\hline IX нейтрофіли & 0,7850 & 1,1200 & 0,31373 & 0,040503 & 0,000179 \\
\hline ЯІ нейтрофіли & 3,6700 & 5,4400 & 0,85190 & 0,109980 & 0,000012 \\
\hline CX нейтрофіли & 15,2450 & 16,1250 & 0,57699 & 0,074489 & 0,000000 \\
\hline МЗЯ нейтрофіли & 3,7150 & 4,8400 & 0,77752 & 0,100378 & 0,000000 \\
\hline IX лімфоцити & 0,6400 & 0,8550 & 0,18240 & 0,023548 & 0,003541 \\
\hline ЯІ лімфоцити & 3,7150 & 5,0650 & 0,78837 & 0,101778 & 0,000000 \\
\hline СX лімфоцити & 13,5000 & 15,5400 & 1,42134 & 0,183494 & 0,000000 \\
\hline МЗЯ лімфоцити & 3,5100 & 3,8800 & 0,25319 & 0,032686 & 0,000000 \\
\hline MЯ & 1,0300 & 1,7050 & 0,39390 & 0,050853 & 0,000233 \\
\hline \multicolumn{6}{|l|}{$\begin{array}{c}\text { Показники групи } \\
\text { порівняння }\end{array}$} \\
\hline GPO & 0,2500 & 0,4250 & 0,15550 & 0,024587 & \\
\hline GRD & 0,0305 & 0,0900 & 0,04447 & 0,007031 & \\
\hline GST & 0,2100 & 0,4400 & 0,16967 & 0,026828 & \\
\hline ОМБ 356 & 1,0540 & 2,1000 & 0,74816 & 0,118294 & \\
\hline ОМБ 370 & 0,9682 & 1,8605 & 0,65596 & 0,103717 & \\
\hline ОМБ 430 & 0,2397 & 0,6381 & 0,24995 & 0,039520 & \\
\hline ОМБ 530 & 0,1487 & 0,2191 & 0,05590 & 0,008839 & \\
\hline периметр ядра & 59,5400 & 73,1650 & 8,94381 & 1,414141 & \\
\hline площа ядра & 272,9100 & 322,1900 & 28,26447 & 4,469006 & \\
\hline міп оптична щільність & 58,0500 & 60,9500 & 3,20696 & 0,507065 & \\
\hline мах оптична щільність & 90,9000 & 105,7000 & 10,55662 & 1,669148 & \\
\hline діапазон мінливості & 34,9500 & 44,0500 & 6,23921 & 0,986506 & \\
\hline відношення ядер & 0,5250 & 1,1100 & 0,32765 & 0,051806 & \\
\hline відсоток AAX & 85,9500 & 99,6000 & 9,33253 & 1,475602 & \\
\hline середнє значення АAX & 1,5050 & 1,9950 & 0,44296 & 0,070038 & \\
\hline середня кількість AX & 2,8800 & 3,6550 & 0,42475 & 0,067159 & \\
\hline IX епітеліоцити & 0,6000 & 1,0500 & 0,27870 & 0,044067 & \\
\hline ЯІ епітеліоцити & 3,7000 & 5,4200 & 0,85065 & 0,134500 & \\
\hline СX епітеліоцити & 13,5950 & 15,9700 & 1,44940 & 0,229170 & \\
\hline МЗЯ епітеліоцити & 6,0800 & 6,8000 & 0,48988 & 0,077456 & \\
\hline IX нейтрофіли & 1,0450 & 1,2450 & 0,21606 & 0,034162 & \\
\hline ЯІ нейтрофіли & 5,2650 & 5,8150 & 0,55895 & 0,088378 & \\
\hline СХ нейтрофіли & 16,2300 & 17,2850 & 0,67510 & 0,106743 & \\
\hline МЗЯ нейтрофіли & 5,0250 & 5,8400 & 0,57343 & 0,090667 & \\
\hline IX лімфоцити & 0,7400 & 1,0150 & 0,16154 & 0,025542 & \\
\hline ЯІ лімфоцити & 5,0250 & 5,7650 & 0,61070 & 0,096561 & \\
\hline СX лімфоцити & 15,4450 & 16,5250 & 0,79602 & 0,125862 & \\
\hline МЗЯ лімфоцити & 4,9300 & 5,8100 & 0,65163 & 0,103032 & \\
\hline МЯ & 1,4100 & 1,8850 & 0,45613 & 0,072120 & \\
\hline
\end{tabular}


Результати множинного факторного аналізу

\begin{tabular}{|l|r|r|}
\hline \multicolumn{1}{|c|}{ Показники досліджуваної групи } & Factor & Factor \\
\hline GRD & $-0,123717$ & $-0,286848$ \\
\hline GST & $-0,621130$ & $-0,362833$ \\
\hline ОМБ 356 & 0,715128 & $-0,164055$ \\
\hline ОМБ 370 & 0,689375 & $-0,165945$ \\
\hline периметр ядра & $-0,293044$ & $-0,020527$ \\
\hline площа ядра & $-0,016728$ & $-0,091849$ \\
\hline міп оптична щільність & 0,240581 & $-0,744166$ \\
\hline мах оптична щільність & 0,127250 & 0,486871 \\
\hline діапазон мінливості & 0,620475 & 0,039202 \\
\hline середнє значення АAX & $-0,534022$ & $-0,147272$ \\
\hline середня кількість AX & $-0,249803$ & 0,064917 \\
\hline ЯI епітеліоцити & 0,107894 & $-0,486489$ \\
\hline СХ епітеліоцити & $-0,141299$ & 0,045917 \\
\hline МЗЯ епітеліоцити & $-0,236572$ & $-0,587422$ \\
\hline IX нейтрофіли & $-0,347177$ & $-0,400113$ \\
\hline ЯI нейтрофіли & $-0,344123$ & $-0,077899$ \\
\hline СX нейтрофіли & 0,447005 & $-0,117839$ \\
\hline МЗЯ нейтрофіли & $-0,248836$ & $-0,038659$ \\
\hline IX лімфоцити & 0,582627 & $-0,035099$ \\
\hline ЯI лімфоцити & $-0,258119$ & 0,435592 \\
\hline СX лімфоцити & 0,475194 & $-0,305158$ \\
\hline М3Я лімфоцити & $-0,114294$ & $-0,288962$ \\
\hline МЯ & $-0,145307$ & $-0,246719$ \\
\hline Ехр1.Уаг & 3,534877 & 2,289352 \\
\hline Рrр.Тотl & 0,153690 & 0,099537 \\
\hline
\end{tabular}

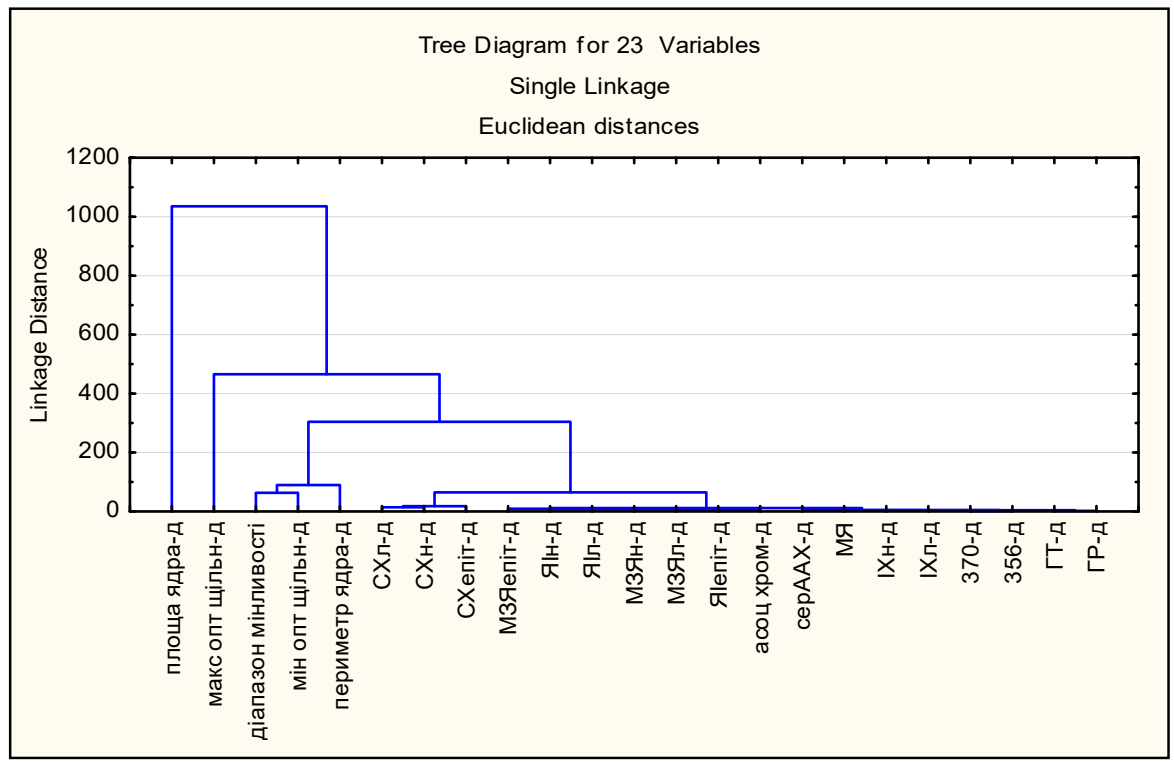

Рис. 1. Евклідові відстані між досліджуваними факторами довголіття. 
3 метою встановлення найвагоміших взаємозв'язків всередині двох кластерів застосовано методику множинного кореляційно-регресійного аналізу.

Шляхом поступового вилучення несуттєвих взаємозв'язків отримали дві математичні моделі (1, 2). Перша 3 них:

$$
Y_{1}=-0,270+0,974 * X_{1}+0,570 * X_{2}
$$

де $\mathrm{Y}_{1}$ - ОМБ 356, $\mathrm{X}_{1}$ - ОМБ 370, $\mathrm{X}_{2}$ - діапазон мінливості ядер епітеліоцитів СОРП.

При цьому, коефіцієнт множинної кореляції дорівнював $\mathrm{R}=0,990$; коефіцієнт детермінації $\mathrm{R}^{2}=$ 0,980, тобто розглянуті два чинники; коефіцієнт поєднаної детермінації adj $\mathrm{R}^{2}=0,979$; $\mathrm{p}<0,001$.

Отримані результати свідчать, що між $\mathrm{X}_{1}$ i $\mathrm{X}_{2}$ 3 одного боку, та $\mathrm{Y}_{1}-3$ іншого, наявний сильний достовірний взаємозв'язок, математичною моделлю якого $€$ отримане рівняння множинної регресії. В цілому, обидва чинники впливають на результуючу ознаку на 97,9\%, а поєднаний їх вплив - на 97,9\%.

тора 2:

Друге рівняння множинної регресії для фак-

$$
\mathrm{Y}_{2}=40,126+0,578 * \mathrm{X}_{3}-0,230 * \mathrm{X}_{4}
$$

де $\mathrm{Y}_{2}$ - мінімальна оптична щільність ядер епітеліоцитів СОРП, Х3 - МЗЯ епітеліоцитів СОРП, $\mathrm{X}_{4}-$ МЗЯ нейтрофілів.

Для цього рівняння коефіцієнт множинної кореляції дорівнював $\mathrm{R}=0,618$; коефіцієнт детермінації $\mathrm{R}^{2}=0,382$, тобто розглянуті два чинники; коефіцієнт поєднаної детермінації $\operatorname{adj} \mathrm{R}^{2}=0,360$; $\mathrm{p}<0,001$.

Отримані результати свідчать, що між $\mathrm{X}_{3}$ i $\mathrm{X}_{4}$ та $\mathrm{Y}_{2}$ існує середньої сили достовірний взаємозв'язок. При цьому, обидва чинники впливають на результуючу ознаку на $38,2 \%$, а поєднаний їх вплив становить $36,0 \%$.

Тобто взаємозв'язки у другій моделі значно слабші, ніж у першій.

Висновки. Таким чином встановлені взаємозв'язки між деякими цитогенетичними показниками довгожителів Прикарпаття, які дали змогу сформувати дві математичні моделі рівнянь множинної регресії (за діапазоном мінливості ядер СОРП, мінімальною оптичною щільністю, МЗЯ епітеліоцитів СОРП та МЗЯ нейтрофілів та ОМБ).

\section{References:}

1. Sydorenko A, Эndrius $H$. OON vozghlavliaet prohrammu yssledovanyi starenyia $\mathrm{v}$ 21-M stoletyy. Uspekhy herontolohy. 2000;3(4):269-70.

2. Alydzhanova XH, Kaurov BA, Artemeva OV. Dolhozhytelstvo: sotsyalnыe, klynycheskye y nekotorыe metabolycheskye aspektы. Uspekhy herntolohyy. 2010; 23(4):611-20.

3. Anysymov VN. Molekuliarnыe y fyzyolohycheskye mekhanyzmы starenyia. Sankt Peterburh: Nauka; 2003. 468s.4. Beekman M, Nederstigt C, Suchiman H. Genome-wide association study (GWAS)-identified disease risk alleles do not compromise human longevity. Proc. Natl. Acad. Sci. USA. 2010; 107:18046-9.
5. Bonomini F, Rodella LF, Rezzani R. Metabolic Syndrome, Aging and Involvement of Oxidative Stress. Aging Dis. 2015; 6:109-20.

6. Babich PN, Gubenko AV, Lapach SN. Primenenie sovremennyih statisticheskih metodov v praktike klinicheskih issledovaniy. Soobschenie vtoroe. Primenenie kriteriya hi-kvadrat. Ukr. med.chasopis. 2003; 32(4):13844.

7. Lapach SN, Gubenko AV, Babich PN. Statisticheskie metodyi v mediko-biologicheskih issledovaniyah s ispolzovaniem Excel. Kyiv: MORION, 2000. P.408.

8. Kozovyi RV. Doslidzhennyia strukturnofunktsionalnoho stanu spadkovoho aparatu dovhozhyteliv z riznykh ekolohichnykh rayoniv Ivano-Frankivskoi oblasti. Halytskyi likarskyi visnyk. 2013; 20(3):26-9.

9. Christensen L, Brasch-Andersen C, Bathum L. A longitudinal study of the effect of GSTT1 and GSTM1 gene copy number on survival. Mechanism of Aging and Development. 2006; 127:597-9.

10. Kozovyi RV, Erstenyuk HM. Pokaznyky okysnyuvalnoi modyfikatsii bilkiv syrovatky krovi u dovhozhyteliv Prykarpattia. Bukovynskyi medychnyi visnyk. 2013; 17(4):76-8.

\section{УДК $311.21+314.118$ \\ ВЫЯВЛЕНИЕ МАТЕМАТИЧЕСКОЙ ЗАВИСИ- МОСТИ МЕЖДУ КАЧЕСТВЕННЫМИ И КОЛИЧЕСТВЕННЫМИ ПОКАЗАТЕЛЯМИ ПРОВЕДЕНОГО ИССЛЕДОВАНИЯ ДОЛГОЖИТЕЛЕЙ}

\section{Р.В. Козовой}

Ивано-Франковский начиональный медищинский университет, кафедра медицинской биологии и генетики, г. Ивано-Франковск, Украина,

ORCID ID: 0000-0002-1806-9773,

e-mail:ruslan_kozoviy@ukr.net

Резюме. Увеличение продолжительности жизни населения планеты закономерно вызывает рост возраст-зависимой патологии. Изучение первичных механизмов старения организма и популяции позволит расширить объем предиктивных мероприятий, направленных на сохранение здоровья. С целью исследования взаимосвязей экзогенных и эндогенных факторов, их влияния на формирование продолжительности жизни проведено комплексное исследование 486 долгожителей и 297 человек группы сравнения, которые длительное время проживали на территории Ивано-Франковской области. После предварительно проведенного комплексного исследования (эпидемиологическим, общеклиническими, клиникогенеалогическим, цитогенетическим, морфоденситометрическим, электронномикроскопическим, молекулярно-генетическим, биохимическим методами), полученные результаты сравнили в двух исследуемых группах. Нами использован математический метод соотношения шансов (Odds Ratio (OR)) и метод парной корреляции Пирсона с помощью приложения Statistica. По результатам сравнительного анализа достоверности разницы данных в группах сравнения 
отобраны те, которые существенно отличаются, для дальнейшего корреляционно-регрессионного факторного анализа. Путем постепенного изъятия несущественных взаимосвязей получили две математические модели. Таким образом, установлены взаимосвязи между некоторыми цитогенетическими показателями долгожителей Прикарпатья, которые позволили сформировать две математические модели уравнений множественной регрессии (за диапазоном изменчивости ядер слизистой оболочки ротовой полости, минимальной оптической плотностью, микроядрами епителиоцитов слизистой оболочки ротовой полости, морфологически измененными ядрами нейтрофилов и окислительными модификациями белков).

Ключевые слова: долголетие, экзогенные факторы, состояние здоровья, продолжительность жизни.

\section{UDC $311.21+314.118$ \\ DETERMINATION OF MATHEMATICAL RELATION BETWEEN QUALITATIVE AND QUANTITATIVE INDICES IN THE CONDUCTED LONGEVITY RESEARCH}

\section{R.V. Kozovyi}

Ivano-Frankivsk National Medical University, Medical Biology and Medical Genetics Department, Ivano-Frankivsk, Ukraine, ORCID ID: 0000-0002-1806-9773, e-mail: ruslan_kozoviy@ukr.net

Abstract. Nowadays, the problem of complex action of environmental factors on living organisms is in the focus of modern medical genetics research. Different kinds of organisms have roughly the same set of reactions to the effects of mutagens. The increasing of mutagenic load to the level capable to double the frequency of mutations in a human being can lead to significant changes in the body system. This is especially true for old people, since aging enlarges the intensity of the mutation process through degradation of reparative systems, increasing sensitivity to the action of negative factors, resulting in a more rapid decreasing of vitality.

Aging inheres most of all living organisms and takes all levels of living being organization: from molecular to organismal genetics. According to the modern concepts of cell theory of aging, the most important factors are the accumulation of cellular disorders, weakening mechanisms of surviving and cell and tissues' recovering. The most common among them there are spontaneous mutations in somatic cells, including structural aberrations of chromosomes. In multivariate aging the latter play significant role. Studying various cytogenetic and molecular genetic disorders in most cases the frequency of their occurrence increasing with age was found. Chromosomal aberrations, micronuclei, the losing of telomeric repeats, mutations in glycophorin locus, DNA's breakings, and so on. The above-mentioned research confirms the important role of genetic factors in the development of such a multifactorial trait, as life expectancy. In order to study the relationship between exogenous and endogenous factors for life expectancy, a comprehensive study of 486 long-living people and 297 individuals of control group was conducted in Ivano-Frankivsk region. After the preliminary complex study (epidemiological, general clinical, clinical-genealogical, cytogenetic, morphodensitometric, electron-microscopic, moleculargenetic, biochemical methods), the obtained results were compared in the two studied groups by correlation and multifactorial analysis. We used the Odds Ratio (OR) mathematical odds ratio method and Pearson's paired correlation method using Statistica. According to the results of the comparative analysis of the significance of the difference in the data in the comparison groups, those that differ significantly are selected for further correlation-regression factor analysis. By gradually removing the irrelevant relationships, two mathematical models were obtained. Found, that the biggest chance to reach longevity have people, that lived in favorable environmental conditions or people, that have high level of xenobiotics detoxification enzymes. Reliable significance on formation livelong and active life had compliance of naturally biorhythms, restrict diet, physical activity, absence of professional hazard and bad habits. In this way the relationships between some cytogenetic indicators of long-livers in the Precarpathian region were established, which made it possible to form two mathematical models of equations of multiple regression (the range of variability of the nuclei of the mucous membrane of the oral cavity, the minimum optical density, micronuclei of the oral mucosa epitheocytes, morphologically altered neutrophil nuclei and oxidative modifications of proteins).

Keywords: longevity, exogenous factors, health status, life expectancy. 